IZA DP No. 6048

Foreign Direct Investment, Black Economic Empowerment and Labour Productivity in South Africa

Anagaw Derseh Mebratie Arjun S. Bedi

October 2011 


\title{
Foreign Direct Investment, Black Economic Empowerment and Labour Productivity in South Africa
}

\author{
Anagaw Derseh Mebratie \\ ISS, Erasmus University Rotterdam \\ Arjun S. Bedi \\ ISS, Erasmus University Rotterdam, \\ ZEF and IZA
}

Discussion Paper No. 6048

October 2011

IZA

P.O. Box 7240
53072 Bonn
Germany

Phone: +49-228-3894-0

Fax: +49-228-3894-180

E-mail: iza@iza.org

\begin{abstract}
Any opinions expressed here are those of the author(s) and not those of IZA. Research published in this series may include views on policy, but the institute itself takes no institutional policy positions.

The Institute for the Study of Labor (IZA) in Bonn is a local and virtual international research center and a place of communication between science, politics and business. IZA is an independent nonprofit organization supported by Deutsche Post Foundation. The center is associated with the University of Bonn and offers a stimulating research environment through its international network, workshops and conferences, data service, project support, research visits and doctoral program. IZA engages in (i) original and internationally competitive research in all fields of labor economics, (ii) development of policy concepts, and (iii) dissemination of research results and concepts to the interested public.
\end{abstract}

IZA Discussion Papers often represent preliminary work and are circulated to encourage discussion. Citation of such a paper should account for its provisional character. A revised version may be available directly from the author. 


\section{ABSTRACT \\ Foreign Direct Investment, Black Economic Empowerment and Labour Productivity in South Africa*}

The impact of foreign direct investment (FDI) on domestically owned firms in developing countries has been widely debated in the literature. It has been argued that FDI provides access to advanced technologies and other intangible assets which may spill over to the host country and allow domestic firms to improve their performance. While there is a substantial literature on this issue, for obvious reasons, little is known about the effect of FDI on domestic firms in the African context. Noting this gap, this paper uses two-period (2003 and 2007) firm level panel data from South Africa to examine the impact of foreign direct investment on the labour productivity of domestic firms. A key policy change during this time period was the passage of the broad-based black economic empowerment act (BB-BEE) and we also examine the effect of the interaction between foreign firm ownership and BEE on labour productivity. Regardless of the empirical specification we find no spill over effects and no evidence that a greater degree of BEE compliance by foreign firms influences labour productivity.

JEL Classification: J24

Keywords: $\quad$ FDI, spillover, labour productivity, black economic empowerment, firm, South Africa

Corresponding author:

Arjun S. Bedi

International Institute of Social Studies

Erasmus University Rotterdam

Kortenaerkade 12

2518 AX Den Haag

The Netherlands

E-mail: bedi@iss.nl

\footnotetext{
* Mebratie acknowledges the financial support of the Netherlands Organisation for Scientific Research (NOW-WOTRO). We thank Susan Newman for material help.
} 


\section{Introduction}

Typically, developing countries offer a range of incentives such as income tax rebates, import duty exemptions and infrastructure subsidies to attract foreign direct investment (Aitken and Harrison, 1999; Waldkirch and Ofosu, 2010). In addition to the direct benefits of an additional source of capital, the flow of foreign direct investment (FDI) is expected to yield benefits such as enhanced employment opportunities, foreign exchange, and arguably, most importantly, the prospect of acquiring new technology and other intangible knowledge, which may spill over to the host country and allow domestic firms to improve their performance (see Ramirez, 2006). ${ }^{1}$

The theoretical literature on the motivation for foreign direct investment argues that multinational enterprises (MNE) possess intangible firm specific advantages which allow them to compete successfully in a foreign environment. These firm specific advantages include not only technological know how but skills related to management, distribution, product design, marketing, and other sources that create value in a modern economy (Vahter, 2004). From the perspective of a developing country, Gorg and Strobl (2001) argue that transmission of such intangible knowledge through FDI is an important channel through which developing countries can catch-up with the industrialized world. Gorg and Greenaway (2004) go on to add that whatever the source of return to international enterprises, the only way in which indigenous firms can gain from such flows is if knowledge spills over from MNE to domestic enterprises. ${ }^{2}$

\footnotetext{
${ }^{1}$ Barba and Venables (2005) provide a taxonomy of the potential positive effects of FDI on a host economy into product market effects, factor market effects and spillover effects. The first two effects are often referred to as direct effects, while the third is classified as an indirect effect.

2 There are several channels through which knowledge and technology may spillover from foreign firms to domestically owned firms. According to Görg and Strobl (2001) and Görg and Greenaway (2004) the theoretical literature identifies several spillover channels through which foreign presence may boost domestic firm productivity. This includes, knowledge acquisition through labour mobility, through imitation of products, production, advertising and marketing strategies, and through competition. On the last channel, while competition may force some domestic firms to become more productive it may cause others to exit the industry and/or reduce production and productivity by drawing away both demand and skilled workers.
} 
While theoretically there appear to be a range of positive effects associated with FDI, this view is not uncontested and there are disagreements on the consequences of FDI on the long run growth trajectory of developing countries. Initial foreign investment flows may be outweighed by capital transfers over the longer run. For instance, dependency school theorists argue that foreign investment is harmful to the long-term economic growth of developing nations as control over resources which may have been used for national development flows to MNCs (see Fan, 2002). Foreign subsidiaries also exhibit a strong tendency to remit profits by manipulating prices, and the type and quantity of their international transactions are mostly kept within the boundaries of the firm (Waldkirch and Ofosu, 2010).

Against this background, whether FDI is likely to have a positive effect on long-run growth in a developing country is likely to depend on the extent to which intangible assets and the technological know how from MNCs seeps into and is embedded into the wider local economy. Beginning with the pioneering work of Caves (1974) this view has spawned a large empirical literature which attempts to identify whether the presence of foreign firms is associated with improved productivity of domestic firms. While a brief review of this literature is provided in the following section, for obvious reasons, very little is known about the effect of FDI on domestic firms in the African context (exceptions are Waldkirch and Ofosu, 2010 and Bwalya, 2006). Noting this gap, this paper draws on two-period (2003 and 2007) panel data from South Africa to analyse the effect of foreign direct investment on the labour productivity of domestic firms. A relatively unique aspect of South Africa is that during this period a key legal measure which may have had a bearing on the effect of FDI on domestic firms was the passage of the broad-based black economic empowerment act (BBBEE). We examine the effect of complying with some of the BEE measures on labour productivity and in particular the interaction between foreign firm ownership and BEE. 
To preview our results we find no evidence of either positive or negative spillovers to domestic firms and no evidence that a greater degree of BEE compliance by foreign firms influences labour productivity. The results are robust to the use of different definitions of foreign presence. The rest of the paper unfolds as follows: Section two contains a review of the existing literature. Section III provides a brief introduction on the environment for foreign investment in South Africa, section IV outlines the empirical approach, section V and section VI discuss the data and the empirical results, respectively, while the final section concludes.

\section{A review of the empirical literature}

There is a substantial literature on the effect of foreign presence on the productivity of domestic firms. Early contributions include the work by Caves (1974) and Globerman (1979). Based on an analysis of the effect of FDI on manufacturing industries in Canada and Australia, Caves pointed out that FDI boosts the productivity of domestic firms through the competitive pressure induced by foreign firms. Soon after, Globerman (1979) confirmed that the labour productivity of domestic firms was positively correlated with the presence of FDI in Canada. In a similar vein, Blomstrom's (1983) study on Mexico - probably the first study on a developing country - reported that foreign presence in an industry had a positive effect on industrial productivity. While these pioneering studies uniformly found evidence of positive FDI spillovers, they were based on cross-section data and did not account for the potentially endogenous flow of foreign direct investment to more productive firms and industries.

A more recent, so-called second generation literature which focuses mainly on transition and developing countries and relies on panel data provides a more nuanced picture. This literature, commencing with the paper by Haddad and Harrison (1993) uses panel data to examine the effect of foreign presence on labour productivity of domestic firms in Morocco. The authors attribute the lack of a spillover effect to the technology gap between foreign and domestic firms. In a marked 
reversal from the earlier cross-section data based literature, Aitken and Harrison (1999) use panel data from Venezuela to conclude that foreign investment is associated with negative spillover effects. In a similar vein, although there are exceptions, papers based on several Eastern European countries tend to find a zero (Konings, 2001 for Romania; Damijan et al. 2003; Vahter, 2004) or negative spillover effect (Djankov and Hoekman 2000; Konings, 2001 for Bulgaria). ${ }^{3}$

Turning to Sub-Saharan Africa, Bwalya (2005) analyses inter- and intra-industry spillovers and finds that in Zambian manufacturing, foreign presence has a positive inter-industry effect through backward linkages while there is evidence of negative intra-industry effects on domestic firms. Waldkirch and Ofosu (2010) reach a similar conclusion. Their analysis of manufacturing firms in Ghana reveals that foreign presence in a sector has a negative effect on the labour productivity of domestically owned firms. The stylized explanation for the negative intra-industry effect is that due to their firm specific advantages, MNCs face a lower marginal cost which allows them to compete more successfully in product and factor markets and to attract demand and talent to the detriment of domestic firms. While competitive pressures may in the long run induce efficiency through knowledge spillovers, in the short run FDI flows may be associated with negative consequences for domestic firms. This hypothesis finds support in the case of China (see Liu, 2008) but Waldkirch and Ofosu (2010) do not find that this holds in the case of Ghana. In sharp contrast to the findings for Eastern European and African countries, a number of papers based on panel data from Asia report a positive spillover effect. This includes, among others work by Kathuria on India (2002), Thuy's (2005) work on Vietnam and Liu (2008) on China.

While the difference in empirical findings across countries may be due to differences in absorptive capacity, firm and industry heterogeneity or may occur through inter-industry rather than

${ }^{3}$ Lutzand and Talavera (2004) for Ukraine and Bedi and Cieslik (2004) and Hagemejer aand Kolasa (2008) for Poland report positive effects of foreign presence on labour productivity, wages and output growth, respectively. 
intra-industry linkages, it is also likely that the outcomes of spillover analysis are affected by differences in the type of data used (cross-section versus panel), the unit of analysis (firm or industry level) the measure of foreign ownership (share of output, employment or capital) and the form of the dependent variable (labour productivity, total factor productivity).

To systematically explore the effect of study-specific features on the findings and to guide the empirical work in this paper we carried out a meta-analysis of 30 studies conducted on developing and transition countries. ${ }^{4}$ These 30 studies yielded a total of 130 observations and among other outcomes, the absolute value of the t-statistic on the spillover variable from these studies was regressed on study-specific characteristics. The list of studies included in the meta-analysis and a set of estimates are provided in Tables 1 and 2, respectively while details on the analysis are available in Mebratie (2010).

The meta-analysis yields three key points which have a bearing on our analysis. First, studies which rely on industry level and cross-section data are more likely to find statistically significant spillover effects as compared to papers that use firm-level panel data. This may be expected as firmlevel panel data allows researchers to control for time-invariant differences in productivity across sectors that might be correlated with foreign presence which is not possible with the use of crosssection industry level data. Second, the outcome measures used across various studies - labour productivity, total factor productivity, output growth - are not systematically linked to the spillover finding. In other words the results are not sensitive to the choice of the dependent variable. Third, papers that measure foreign ownership in terms of share of capital as opposed to share of employment or output are more likely to report statistically significant findings. There is also no

\footnotetext{
${ }^{4}$ While meta-analysis is frequently used in medical, psychological and educational research, its application in economics is limited to a relatively small but increasing number of studies. For example, Card and Krueger (1995) use the methodology to assess the employment effects of minimum wages. Smith and Huang (1995) to examine the relationship between willingness to pay for reductions in air pollution and Sinani and Meyer (2009) apply it study the relationship between multinational companies and productivity spillovers.
} 
evidence of publication bias and echoing the previous discussion, papers based on data from Asia are more likely to report statistically significant findings as compared to other transition and developing countries. Drawing on this meta-analysis we use firm-level panel data to investigate spillover effects. We use labour productivity as our outcome measure, define foreign ownership in terms of share of capital and examine the sensitivity of the estimates to the outcome and foreign presence measures.

\section{Foreign direct investment and black economic empowerment in South Africa}

In the decade leading up to the end of apartheid in 1994, South Africa witnessed a net outflow of capital. However, since then, except for a net outflow in 2006, the country has been a net recipient of FDI. From a small flow amounting to US\$10 million in 1993, net FDI inflow in 2009 amounted to US $\$ 5.7$ billion and reached a peak of US $\$ 9$ billion in 2008 . While it varies across years, at least in 2008 and 2009, FDI flows accounted for 10 to 15 percent of gross capital formation. Analysis of FDI flows between 1994 and 2005 shows that they are concentrated in three sectors, financial services, accounting for 34 percent, followed by mining and manufacturing, at 30 and 28 percent, respectively. The bulk of FDI to South Africa (about 86 percent) comes from Europe with the United Kingdom as the dominant source of investment. In the Sub-Saharan African context, over the period 2005-2009, South Africa has been amongst the top three recipients of FDI along with Angola and Nigeria accounting for about 10 percent of FDI flowing to the region. ${ }^{5}$

After 1994, the new government rapidly adopted outward looking policies designed to attract foreign capital and successive governments have stressed the importance of FDI for economic growth. A body called the International Investment Council was set up in 1999 to enable foreign investment and ease the administrative burden on foreign investors (IGD, 2005). According to UNCTAD (2006), over the last 10 years, South Africa has provided several investment incentives

\footnotetext{
5 All figures are in current prices at current exchange rates and are from UNCTAD, or from http://devdata.worldbank.org/AAG/zaf_aag.pdf.
} 
for foreign businesses. Measures include reduced import tariffs and subsidies, removal of limits on hard currency repatriation and a lowering of the corporate tax rate. Capital invested in South Africa, as well as interest and profit, can be freely repatriated and except in the financial sector, foreign investors may have 100 per cent ownership. In addition, the Department of Trade and Industry (DTI) provides incentives through its Foreign Investment Grant (FIG) programme. Under this scheme, foreign investors receive a cash incentive if they invest in new businesses in specific industries. The FIG provides up to a maximum of $15 \%$ cost recovery for foreign entrepreneurs to import new machinery and equipment (SADTI, 2008). The country has signed double tax avoidance agreements with a number of countries (UNCTAD, 2006) and provides an environment designed to protect intellectual property (SADTI, 2008).

On the flip side, since 1994, South Africa has been engaged in a process of black economic empowerment, which among other measures is aimed at conferring ownership, management and control of South African firms to the non-white population. ${ }^{6}$ While the first instance of the transfer of equity from a white company to a black owned consortium took place in 1993, after 1994 such ownership transfers became more frequent. In general the process of ownership transfer was a result of private initiatives and was not coordinated by the government. Dissatisfaction with such an approach led to the creation of a BEE commission in 1999, which released its report in 2001. The commission articulated the notion of "Broad-based Black Economic Empowerment" which went beyond ownership and included seven dimensions of BEE "elements of human resource development, employment equity, enterprise development, preferential procurement, as well as investment, ownership and control of enterprises and economic assets" (Government of South Africa, 2002, p. 12). In 2003, the recommendations of the BEE commission were translated into a strategy document which was notable for the development of a scorecard which provided weights to

${ }^{6}$ According to the Broad-Based Black Economic Empowerment Act, 2003, "black people" is a generic term which includes Africans, Coloureds and Indians. 
the seven dimensions of $\mathrm{BEE}$ and clarified what it meant for a company to be BEE compliant. Subsequently, on January 9, 2004, the Broad-based Black Economic Empowerment Act was signed into law. ${ }^{7}$

With regard to foreign direct investments, while foreign firms wishing to invest in South Africa are exempt from the ownership clause they do have to spend time on BEE compliance issues and they are expected to purchase material inputs and services (preferential procurement) from black empowered companies. ${ }^{8}$ Thus, as pointed out by Makwiramiti (2011), BEE measures may limit the attractiveness of South African as a destination for FDI, but more pertinently for this paper, as is discussed in the following section, such measures may have a bearing on foreign firm productivity and on spillover effects to domestic firms.

\section{An analytical framework}

The desire to attract foreign direct investment is clearly linked to the benefits thought to be associated with its flow. A prominent benefit is that the flow of FDI allows developing and transition countries access to firm-specific intangible proprietary productive knowledge which multinationals may possess. Provided that multinationals do have such knowledge, then it maybe expected that foreign ownership of a firm is likely to enhance firm productivity. At the same time, through various channels, domestically owned firms may also benefit from such knowledge flows. These two hypotheses - foreign ownership is associated with higher productivity and that domestic firms operating in industries that receive FDI experience productivity gains, that is, intra-industry knowledge spillovers, have spawned a large empirical literature.

\footnotetext{
${ }^{7}$ See Acemoglu, Gelb and Robinson (2007) for more details on BEE policies.

8 The time dimension includes total senior management's time spent on dealing with issues and requirements associated with Black Economic Empowerment (such as policy, ownership, procurement, marketing and sales, and labor/employment issues). A black empowered company is defined as one which is at least 25.1 percent owned and managed by black people.
} 
We draw on this literature to develop a framework which is tailored to the two-period panel data at hand. Consider a production function where output $Y$ for firm $i$ in industry $j$ in period $t$ is treated as a function of capital $(K)$, labour $(L)$ and access to technology, $Y_{i j t}=A_{i j t} K_{i j t}{ }^{\alpha} L_{i j t}{ }^{\beta}$. Amongst the factors included in $A_{i j t}$ are variables that capture a firm's direct and indirect access to intangible knowledge from foreign sources. Specifically, direct access is proxied by the percentage of a firm's foreign equity $\left(F D I_{j i t}\right)$ while indirect access (spillovers) is captured by foreign equity participation at the level of the industry $\left(F D I_{j t}\right)$. With regard to the outcome of interest, as discussed in section II, there is no agreement on the appropriate measure and authors have used output growth, total factor productivity or labour productivity. Considering the context and the potential importance of labour productivity in improving living standards and wages, as argued among others by Steindel and Stiroh (2001), Buckley et al. (2007), and Mahmood (2008) we opt for labour productivity (sales per worker) as our key outcome measure. ${ }^{9}$

Manipulating, expanding and log-linearising the production function yields,

$$
y_{i j t}=\beta_{0}+\beta_{1} T+\beta_{2} k_{i j t}+\beta_{3} F D I_{i j t}+\beta_{4} F D I_{j t}+\beta_{5} F D I_{i j t} * F D I_{j t}+\gamma \sum X_{j j t}+a_{i}+\varepsilon_{i j t},
$$

where, log sales per worker (labour productivity) is treated as a function of a time dummy $(T)$, fixed capital per worker $\left(k_{i j t}\right)$, measures of FDI and other productivity related inputs $X_{i j t}$ which includes the share of skilled workers in a firm, firm size, and a proxy for firm investment in quality as measured by possession of an international quality certificate such as ISO9000. $a_{i}$ is a firm fixed effect, $\varepsilon_{i j t}$ is a time-variant error term and the $\beta_{i}$ 's and $\gamma$ 's are coefficients to be estimated. If foreign ownership in a firm is associated with increased labour productivity then $\beta_{3}$ should be positive and if there are intra-industry knowledge spillovers from foreign firms to domestically owned firms then $\beta_{4}$ should

\footnotetext{
${ }^{9}$ Arguing for the use of labour productivity as an appropriate measure, Buckley et al. (2007) point out that since returns to foreign capital flow abroad, the growth enhancing effect of FDI may be considered as noteworthy if intangible assets are transferred to the domestic economy through increased managerial and labour productivity.
} 
also be positive. The interaction term $\left(F D I_{j i t} * F D I_{j t}\right)$ is included to examine the effect of intraindustry spillover effects on other foreign firms in the industry. A positive coefficient indicates that foreign firms gain from the presence of other foreign firms in the industry.

The key econometric concern associated with estimating (1) is that foreign investment in a particular firm or industry is not exogenous and may be driven by unobserved factors that drive labour productivity. For instance, if multinationals are more likely to invest in more productive domestic firms then the effect of foreign ownership on labour productivity $\left(\beta_{3}\right)$ is likely to be overestimated while the effect of foreign ownership on firms that remain domestically owned is likely to be underestimated $\left(\beta_{4}\right)$. On the other hand if multinationals invest in less productive firms, where they may anticipate growth, then the own-firm effect is likely to be underestimated while the effect of foreign presence on firms that remain domestically owned is likely to be overestimated. To the extent that unobserved attributes that drive labour productivity are time-invariant, the inclusion of firm fixed-effects $\left(a_{i}\right)$ is likely to mitigate the effects of reverse causality. It is of course possible that even after controlling for fixed-effects, due to time-varying unobserved heterogeneity, FDI flows and unobserved factors that determine labour productivity are jointly determined and the $\operatorname{Cov}\left(F D I_{i j t}, \varepsilon_{i j t}\right) \neq 0$. In the forthcoming sections we discuss this possibility and the effects on the estimates in more detail.

While the main equation of interest is (1) we estimate several specifications of this model to examine the sensitivity of the estimates. Most notably, we examine the effect of BEE compliance, as measured by the proportion of domestically sourced inputs procured from black empowered companies, on the productivity of foreign firms. Since and due to the passage of the BEE Act in January 2004 foreign firms may have felt obliged to source some of their inputs from BE companies, which is akin to an input tariff, and in turn may be expected to have a negative effect on 
foreign firm productivity. ${ }^{10}$ At the same time by forcing foreign firms to source inputs from black empowered companies such a policy may encourage greater vertical interactions between foreign and domestic firms which may work towards enhancing the productivity of domestically owned firms. In this paper, since we focus on horizontal/intra-industry interactions, if compliance with BEE is associated with a reduction in foreign firm productivity then it potentially reduces the scope for intra-industry spillovers. To empirically examine these effects we estimate,

$$
\begin{aligned}
y_{i j t}= & \beta_{0}+\beta_{1} T+\beta_{2} k_{i j t}+\beta_{3} F D I_{i j t}+\beta_{4} F D I_{j t}+\beta_{5} F D I_{i j t} * F D I_{j t}+\beta_{6} B E E_{i j t} \\
& +\beta_{7} B E E_{i j t} * F D I_{i j t}+\beta_{8} B E E_{i j t} * F D I_{j t}+\gamma \sum X_{i j t}+a_{i}+\varepsilon_{i j t},
\end{aligned}
$$

where, the coefficient on $B E E_{i j t}$ measures the direct effect of compliance on firm productivity. The specific effect on foreign firms is measured by the coefficient on $B E E_{j j t} * F D I_{i j t}$ and the effect of the interaction between BEE compliance and spillovers is measured by $\beta_{8}$. Since the BEE act was only passed in 2004, estimates based on (2) may be considered difference-in-differences estimates of the effect of complying with an element of the act on productivity. While (2) does include firm-level fixed effects which allows us to provide estimates that at least control for time-invariant unobserved characteristics, since compliance with BEE is likely to be endogenous we do not purport to provide causal estimates of the effect of BEE measures. ${ }^{11}$ Our main concern is to examine whether compliance with the act may have affected the productivity of foreign firms and hampered their ability to generate intra-industry learning.

\section{Data and descriptive statistics}

The empirical work presented in this paper is based on a panel data set constructed by combining two rounds of surveys collected as part of the World Bank's Regional Program on Enterprise

\footnotetext{
${ }^{10}$ According to the codes of good practice associated with the BB-BEE act, preferential procurement has a 20 percent weight in the computation of the BEE score card and during the first five years of the policy the preferential procurement target was set at 50 percent.

${ }^{11}$ For instance, foreign firms that are less productive and would like to obtain government contracts or extract political favors may be more willing to comply with preferential procurement policies. If this is the case estimates which do not correct for the potential endogeneity may exaggerate the negative link between BEE measures and productivity.
} 
Development. These World Bank Enterprise Surveys (WBES) canvassed in 2003 and 2007 use the same survey instruments and the same sampling methodology and are administered to a representative sample of firms in the non-agricultural formal private economy. ${ }^{12}$ In the case of South Africa, firms were selected based on simple stratified sampling from a list of all registered enterprises in Johannesburg, Cape Town, Port Elizabeth and Durban. Zones were randomly selected from each of the four cities and individual firms were randomly selected from zone-specific lists of firms. The surveys contain information on a range of variables which support firm-level productivity analyses including most importantly for this paper a firm's ownership status.

The surveys provide establishment level information for 603 firms in 2003 and 1057 firms in 2007. Although the surveys were designed to yield panel data, the panel component is somewhat limited. Of the 603 firms surveyed in 2003, only 191 were surveyed again in 2007. Thus, 412 firms were surveyed only in 2003 and 866 firms were surveyed only in 2007. The distribution of firms in terms of their ownership status is provided in Table 3. While the panel component is restricted to only 191 firms it does not imply that the firms that were not surveyed in 2007 dropped out or that a large number of new firms commenced operations between 2003 and 2007. For instance of the 866 firms surveyed only in 2007, 633 (73.1\%) were operating before 2003 but were not included in the 2003 survey.

An immediate concern, in terms of the validity of the empirical work is whether the 412 firms not canvassed in the 2007 survey were excluded because they exited the industry or due to other systematic factors or whether their omission is driven by non-systematic random factors. If less productive firms systematically exit the survey then analyses based on the remaining more productive firms is unlikely to yield consistent estimates of the FDI-productivity relationship. To

12 The Enterprise Surveys are designed to yield panel data in order to pinpoint how and which changes in the business environment affect firm-level productivity over time and across countries. For details see (World Bank, Understanding the questionnaire, 2008 and www.enterprisesurveys.org). 
examine this issue we estimate a probit model where the dependent variable drop-out takes the value one for firms that are not canvassed in the second wave and zero otherwise and the independent variables are various firm characteristics (see Baulch and Quisumbing, 2010 for a similar test). The idea is to examine whether firm characteristics are systematically linked to sample retention. As shown in Table A2, none of the variables are statistically significant which supports the idea that firms that were excluded from the survey are not systematically different from firms that are retained in the sample. ${ }^{13}$

As shown in Table 3, of the 191 firms included in both surveys, in 2003, 81 percent are domestically owned. ${ }^{14}$ Between 2003 and 2007 the proportion of domestically owned firms falls to 76 percent. In terms of location, the bulk of the firms are located in Johannesburg with foreign firms far more likely to be located in this city as compared to domestic firms (see Table 4). There are strong similarities with regard to industrial distribution with both foreign and domestic firms most likely to be operating in the fabricated metal products, chemicals and food processing industries (see Table 5).

The definitions of the variables used in our analysis are provided in Table 6 while Tables 7 and 8 contain descriptive statistics. As shown in Table 8, labour productivity is higher in foreign firms in both years although the differences are only statistically significant in 2007. Both foreign and domestic firms appear to be similarly endowed in terms of capital and labour quality and in neither year are the differences statistically significant. The key difference appears to be firm size. While the bulk of the foreign firms (78 to 86 percent) fall in the category of large firms with 100 or more

\footnotetext{
13 The attrition probit model is based on 473 observations rather than the total number of firms (603) surveyed in 2003. The number of observations falls as information on some of the variables included in the regression is incomplete.

${ }_{14}$ According to the World Bank classification of firms based on ownership status, a firm may be considered as a foreign firm if foreign companies or investors own at least 10 percent of the firm (see World Bank, Understanding the questionnaire, 2008).
} 
employees, only about half of the domestic firms fall in this category (44 to 48 percent). Firms owned by foreigners appear to have been operating for a longer period than domestically owned firms suggesting that foreign investment is more likely in well-established larger firms. While there are concerns about the additional costs that foreign may face due to BEE-compliance, the data show that the costs of such measures may be more onerous for domestic firms. While about 3 percent of senior management time per week is spent on BEE issues in a foreign firm it is 6 percent in a domestic firm. In terms of a more concrete measure, about 14 percent of domestically sourced inputs of foreign firms come from black empowered companies while the corresponding figure for domestically owned firms is 17 percent.

\section{Estimates}

\section{A. FDI and labour productivity}

Table 9 contains several sets of estimates. Columns 1(3) and 2(4) provide estimates based on the cross-section 2003(2007) survey for the entire data set and for the firms included in the panel, respectively. Columns 5 and 6 provide estimates based on the pooled data and column 7 presents estimates controlling for firm fixed-effects. All the estimates based on the cross-section data show that there is a positive link between foreign ownership and productivity. The point estimate suggests that a 10 percent increase in foreign ownership is associated with a 2.7 to 5 percentage point increase in labour productivity. However, this coefficient is precisely estimated only in columns 1 and 5, and thus provides rather weak support for the idea that foreign firms possess intangible productivityenhancing knowledge. There is no evidence to support the claim that domestic firms operating in industries that have a higher rate of foreign participation experience a positive spillover effect. At the same time there is also no support for a negative spillover effect. This may be interpreted in terms of a balance between the positive knowledge enhancing effects of FDI and the potentially negative effect due to the shift of demand from domestic to foreign firms. Alternatively, and more straight 
forward, it may be argued that foreign firms do not possess any superior knowledge compared to domestic firms and hence there is no scope for spillover effects. Indeed the within-estimates are markedly differently from the cross-section estimates. The positive effect of FDI_Firm is replaced by a negative effect although statistically insignificant at conventional levels ( $\mathrm{p}$-value 0.182). ${ }^{15}$ The change between the two sets of estimates suggests that the positive link between FDI and labour productivity observed in columns 1 to 6 is driven by the flow of foreign investments to more productive domestic firms. ${ }^{16}$ This is consistent with the earlier discussion that FDI flows to larger more well-established firms. Once we control for this endogenous flow, through the inclusion of firm-fixed effects, there is no evidence of superior foreign knowledge and also as may be expected, no evidence of spillover effects either to domestic or other foreign firms in the same industry.

As pointed out on the basis of the meta-analysis, identification of spillover effects is particularly sensitive to data type (cross-section versus panel) and the FDI measure of foreign presence. To examine this, Table 10 provides estimates using share of employment in foreign firms rather than foreign ownership as a measure of FDI. The patterns are very similar. The cross-section estimates in columns 1, 4 and 5 provide the impression that there is a positive link between foreign presence and labour productivity while the within-estimates show that foreign ownership is not associated with increased productivity. The change between the cross-section and panel data estimates suggests that the cross-section correlation may have been driven by firm characteristics which appeal to foreign investors. There is no evidence of spill over effects. Aitken and Harrison (1999) point out that spillovers may be geographically restricted in the sense of exerting an effect only on domestic firms located close to foreign firms. To test for this we run a complete set of specifications which includes

\footnotetext{
15 Taking into account the interaction between FDI_Firm and FDI_Industry, at the mean of the foreign presence variable in an industry, the coefficient (std. error) on FDI_Firm is $-0.426(0.318)$.

16 The panel data estimates reported in Table 9 are based on an unbalanced panel consisting of 326 observations. Restricting the analysis to a smaller balanced panel yields similar estimates.
} 
two spillover measures - that is, as in Tables 9 and 10, FDI share in the industry to which a firm belongs and FDI share in the city where a firm is located (see Table A3). The estimates yield patterns that are similar to the baseline specification (Table 9). ${ }^{17}$

\section{B. FDI, BEE and labour productivity}

Table 11 contains estimates of the effect of FDI and BEE on labour productivity. We provide estimates for the 2007 cross-section data based on the full data set and the sample included in the panel (columns 1 to 4 ) while fixed-effects estimates are in columns 5 and 6 . The first point which emerges from columns 1 and 2 is that there is a negative and statistically significant effect of BEE compliance on labour productivity. A 10 percent increase in material procurements from black empowered companies is associated with a 2.3 to 5 percent reduction in productivity. Estimates of the effect of foreign ownership and spillover effects are similar to those reported in Table 9. With regard to firm ownership, there are sharp differences in the source of the negative effect. While the effect of BEE compliance seems to have no effect on the productivity of domestic firms, at the mean level of foreign ownership in the sample, a 10 percent increase in BEE compliance is associated with a substantial 8 to 15 percent reduction in labour productivity. Supporting the idea of a BEE induced decline in foreign firm productivity, the inclusion of the BEE variables leads to an increase in the positive effect of foreign firm ownership on labour productivity. However, there is no evidence of spillover effects.

As pointed out earlier, BEE compliance is endogenous and if less productive firms are more likely to comply then cross-section data estimates will tend to overestimate the negative effect of BEE compliance on productivity. Firm fixed-effect estimates which at least control for time-

\footnotetext{
${ }^{17}$ We split the FDI_Industry variable into the share of joint venture foreign presence in an industry and fully-owned foreign presence in an industry to see whether spillover effects differ across these two types of FDI. Neither of the two measures was statistically significant. Following Liu (2008), we also examine whether there is a time lag between FDI and any potential spillover effects by estimating the effect of FDI in 2003 on labour productivity in 2007 (see Table A4). The estimates show that while foreign ownership in 2003 is associated with increased productivity in 2007 there are no gains for domestic firms. Finally, we also re-estimate the specifications reported in Table 9
} 
invariant unobserved characteristics (columns 5 and 6) yield a picture which is markedly different from the cross-section estimates. There is little evidence of a negative effect of BEE compliance on productivity. The coefficient on this measure is negative but no longer statistically significant. ${ }^{18}$ The coefficient on the interaction between FDI and BEE is not statistically different from zero indicating that foreign firm productivity is not affected by adherence to preferential procurement policies. The differences between the cross-section and the panel data estimates support the idea that foreign direct investment flows to more productive firms and that less productive foreign firms are more likely to comply with BEE. Consequently, after correcting for firm-fixed effects there is a negative although statistically insignificant link between foreign firm ownership and labour productivity and no evidence of spillover effects.

\section{Conclusion}

The impact of foreign direct investment (FDI) on domestically owned firms in developing countries has attracted substantial academic and policy attention. A well-developed literature argues that foreign firms possess proprietary productive knowledge and through interactions with such firms domestic enterprises can enhance their own productivity - a spillover effect. At the same time, there is a concern that foreign companies may have a negative competition effect on domestic firms and attract demand and labour away from domestic firms and cause domestic firms to exit the industry. While a large number of studies have examined the spillover effects of foreign presence on local industries in different countries, efforts to investigate the effect of multinational companies operating in Africa on local firms is limited and this paper sought to fill the gap.

Using a two period (2003 and 2007) panel data of South African manufacturing firms, this study examined the impact of foreign ownership of a firm on its own productivity and on the productivity of domestically-owned enterprises. Estimates based on cross-section data showed that foreign-

\footnotetext{
18 Acemoglu et al. (2007) also find that there is no link between firm-level BEE compliance and firm profitability and labour productivity.
} 
owned firms were more productive than their domestic counterparts. However, panel data based estimates supported the idea that FDI is attracted to more productive firms and conditional on controlling for firm fixed-effects there was no foreign-owned productivity effect. Consistent with the lack of a foreign ownership productivity effect there were no spillover effects either to domestic firms or to other foreign firms operating in the same industry. The estimates were robust to the use of alternative measures of foreign presence, alternative outcome measures and to the split of foreign presence into joint-venture and fully-owned. The zero spillover effect may be contrasted with the findings of Waldkirch and Ofosu (2010) and Bwalya (2006) for Zambia who find negative spillover effects which they attribute to negative competition effects. In the case of South Africa we find zero spillover effects and since there is no evidence that foreign firms are more productive than domestic firms we draw the conclusion that this effect may be attributed to the limited scope for spillovers as foreign firms operating in South Africa, at least between 2003 and 2007, do not appear to have superior intangible productive knowledge as compared to their domestically owned counterparts.

An important policy change during the period which may have had an impact on the operation of foreign enterprises was the passage of the Broad-Based Black Empowerment Act in 2004. While foreign firms are exempt from the act's ownership provision they are expected to follow other elements including preferential procurement of inputs from black empowered companies. Estimates based on the cross-section data showed that compliance with BEE procurement measures were negatively associated with foreign firm productivity. However, on controlling for firm fixed effects the negative influence evaporated, suggesting that less productive foreign owned firms are more like to comply with BEE provisions. The analysis supported the conclusion that after controlling for BEE compliance, foreign firms are not more productive than domestically owned firms and that there is no spillover effect. 
Our analysis focused on the relationship between changes in FDI and changes in labour productivity between 2003 and 2007. Gains from FDI flows may have already materialized by 2003 and hence there maybe limited scope for further learning and spillover effects. There are of course a a variety of other gains associated with FDI which have not been investigated in this paper. Nevertheless, the estimates presented here show that in the South African context for the period under scrutiny there is no evidence of intra-industry knowledge flows. These estimates call into question the continued use of preferential fiscal and tax policies for multinational corporations. 


\section{References}

Aitken, B. and A. Harrison (1999) 'Do Domestic Firms Benefit from Direct Foreign Investment? Evidence from Venezuela', American Economic Review 89(3): 605-618.

Aslanoglu, E. (2000) 'Spill-over Effects of Foreign Direct Investments on Turkish Manufacturing Industry', Journal of International Development 12(8): 1111.

Barba, N. G. and A. Venables (2005) 'Multinational Firms in the World Economy', Journal of International Economics 67(2): 520-524.

Batra, G., Morisse, J. and Saggi, K. (2003) Vertical Linkages between Multinationals and Domestic Suppliers: Whom do they Benefit and Why? University of Southern Methodist: University of Southern Methodist.

Baulch, B. and A. Quisumbing (2010) 'Testing and Adjusting for Attrition in Household Panel Data', Chronic Poverty Research Centre, London.

Bedi, A.S. and A. Cieslik (2002) 'Wages and Wage Growth in Poland: The Role of Foreign Direct Investment', The Economics of Transition 10(1):1-27.

Björk, I. (2005) Spill-over Effects of FDI in the Manufacturing Sector in Chile. Nationalekonomiska institutionen, Lunds universitet.

Blomstrom, M. (1983) 'Foreign Investment and Productive Efficiency: The Case of Mexico', The Journal of Industrial Economics 35(1): 97.

Blomstrom, M. and H. Persson (1983) 'Foreign Investment and Spill-over Efficiency in an Underdeveloped Economy: Evidence from the Mexican Manufacturing Industry', World Development 11(6): 493-501.

Buckley, Peter, Chengqi Wang, and Jeremy Clegg (2007) 'The Impact of Foreign Ownership, Local Ownership and Industry Characteristics on Spillover Benefits from Foreign Direct Investment in China', International Business Review 16 (2): 142-158.

Bwalya, S.M. (2006) 'Foreign Direct Investment and Technology Spillovers: Evidence from Panel Data Analysis of Manufacturing firms in Zambia', Journal of Development Economics 81(2): 514526.

Card, D.E. and A. Krueger (1995) 'Time-Series Minimum-Wage Studies', Princeton University, Industrial Relations Section 85: 238-246.

Caves, R. (1974) 'Multinational Firms, Competition, and Productivity in Host-Country Markets', Economica (London) 41(161): 176.

Chuang, Y. and C. Lin (1999) 'FDI, R\&D and Spill-over Efficiency: Evidence from Taiwan's Manufacturing Firms' Journal of Development Studies, 35: 117-137.

Cuyvers, L., Soeng, R., Plasmans, J. and Bulcke, D.V.d. (2008). Productivity Spill-overs from Foreign Direct Investment in the Cambodian Manufacturing Industry: Evidence from EstablishmentLevel Data. Research Paper 2008-004 edn. University of Antwerp

Damijan, J., M. Knell, B. Majcen and M. Rojec (2003) 'The Role of FDI, R \& D Accumulation and Trade in Transferring Technology to Transition Countries: Evidence from Firm Panel Data for Eight Transition Countries', 27: 189-204.

Djankov, S. and B. Hoekman (2000) 'Foreign Investment and Productivity Growth in Czech Enterprises', The World Bank Economic Review 14(1): 49-64.

Fan, E.X. (2002) 'Technological Spillovers from Foreign Direct Investment', Asian Development Bank, Economics and Research Department.

Globerman, S. (1979) 'Foreign Direct Investment and 'Spillover' Efficiency Benefits in Canadian Manufacturing Industries', The Canadian Journal of Economics 12(1): 42.

Görg, H. and D. Greenaway (2004) 'Much Ado about Nothing? Do Domestic Firms really Benefit from Foreign Direct Investment?', The World Bank Research Observer 19(2): 171-197. 
Görg, H. and E.A. Strobl (2001) 'Multinational Companies and Productivity Spillovers: A MetaAnalysis', The Economic Journal (London) 111(475): F723-F739.

Government of South Africa (2002) South Africa's Economic Transformation: A Strategy for Broad-Based Black Economic Empowerment, http://www.thedti.gov.za/bee/bee.htm. Accessed on September 19, 2011

Haddad, M. and A. Harrison (1993) 'Are there Positive Spillovers from Direct Foreign Investment?: Evidence from Panel Data for Morocco', Journal of Development Economics 42(1): 51-74.

Hagemejer, J. and M. Kolasa (2008) Internationalization and Economic Performance of Enterprises: Evidence from Firm-Level Data. National Bank of Poland.

IGD (2005) Investment Policy in South Africa: An Agenda for Action. CUTS Centre for Competition.

Kathuria, V. (2002) 'Foreign Firms, Technology Transfer and Knowledge Spillovers to Indian Manufacturing Firms: A Stochastic Frontier Analysis', Applied Economics 33(5): 625-642.

Kee, H.L. (2005). 'Foreign Ownership and Firm Productivity in Bangladesh Garment Sector', Development Research Group, The World Bank, Washington DC, USA.

Keini, S.H. (2008) 'Multinational Enterprises, Export and Domestic Firms Productivity in Brazilian Manufacturing Industries', Sociedade Iko Poran.

Kokko, A., M. Zejan and R. Tansini (2001) 'Trade Regimes and Spillover Effects of FDI: Evidence from Uruguay', Review of World Economics 137(1): 124-149.

Kolasa, M. (2008) 'How does FDI Inflow Affect Productivity of Domestic Firms? the Role of Horizontal and Vertical Spill-overs, Absorptive Capacity and Competition', Journal of International Trade \& Economic Development 17(1): 155-173.

Konings, J. (2001) 'The Effects of Foreign Direct Investment on Domestic Firms: Evidence from Firm Level Panel Data in Emerging Economies', The Economics of Transition 9(3): 619-633.

Konings, J. (2001) 'The Effects of Foreign Direct Investment on Domestic Firms: Evidence from Firm Level Panel Data in Emerging Economies', The Economics of Transition 9(3): 619-633.

Liu, X., D. Parker, K. Vaidya and Y. Wei (2001) 'The Impact of Foreign Direct Investment on Labour Productivity in the Chinese Electronics Industry', International Business Review 10(4): 421439.

Liu, Z. (2008) 'Foreign Direct Investment and Technology Spillovers: Theory and Evidence', Journal of Development Economics 85(1-2): 176-193.

Lutz, S. and O. Talavera (2004) 'Do Ukrainian Firms Benefit from FDI?', Economics of Planning 37(2): 77-98.

Mahmood, M. (2008) 'Labour Productivity and Employment in Australian Manufacturing SMEs', International Entrepreneurship and Management Journal 4(1): 51-62.

Makwiramiti, AM (2011) In the name of economic empowerment: A case for South Africa and Zimbabwe, Consultancy African Intelegence, online discussion paper bttp:// www.consultancyafrica.com/. Accessed on August 12, 2011

Marin, A. and M. Bell (2006) 'Technology Spill-overs from Foreign Direct Investment (FDI): The Active Role of MNC Subsidiaries in Argentina in the 1990s', The Journal of Development Studies 42(4): 678-697.

Mebratie, A.D. (2010). 'Foreign Direct Investment and Labour Productivity in South Africa', Research Paper, Institute of Social Studies, The Hague.

Ramirez, M.D. (2006) 'Is Foreign Direct Investment Beneficial for Mexico? an Empirical Analysis, 1960-2001', World Development 34(5): 802-817.

Rattsø, J. and H.E. Stokke (2003) 'Learning and Foreign Technology Spill-overs in Thailand: Empirical Evidence on Productivity Dynamics' Nordic Journal of Political Economy, 29: 47-66. 
SADTI, (2008). South Africa Investment Incentive: An Information Guide to Investors. Department of Trade and industry, South Africa.

Sgard, J. ( 2001). 'Direct Foreign Investment and Productivity Growth in Hungarian Firms, 19921999', CEPII working paper 2001-19 edn.

Sinani, E. and K. Meyer (2009) 'When and Where does Foreign Direct Investment Generate Positive Spillovers? A Meta-Analysis', Journal of International Business Studies 40(7): 1075-1094.

Sjöholm, F. (1999) 'Technology Gap, Competition and Spill-overs from Direct Foreign Investment: Evidence from Establishment Data', Journal of Development Studies 36(1): 53-73.

Smarzynska, B. (2002). 'Does Foreign Direct Investment Increase the Productivity of Domestic Firms : In Search of Spill-overs through Backward Linkages', Policy Research Working Paper Series 2923 edn. The World Bank.

Smith, V.K. and J.C. Huang (1995) 'Can Markets Value Air Quality? A Meta-Analysis of Hedonic Property Value Models', Journal of political economy : 209-227.

Steindel, C. and K. Stiroh (2001) 'Productivity: What is it, and Why do we Care about it?', Business Economics (Cleveland, Obio) 36(4): 13.

Thuy, L.T. (2005) 'Technological Spillovers from Foreign Direct Investment: The Case of Vietnam', School of Economics, University of Tokyo: School of Economics.

UNCTAD (2006) 'The World Investment, Country Profile: South Africa. ' UN, New York and Geneva.

Vahter, P. (2004). 'The Effect of Foreign Direct Investment on Labor Productivity. ' Working Paper No. 32 edn. University of Tartu.

Waldkirch, A. and A. Ofosu (2010) 'Foreign Presence, Spillovers, and Productivity: Evidence from Ghana', World Development 38(8): 1114-1126.

Yudaeva, K., K. Kozlov and N. Melentieva (2003) 'Does Foreign Ownership Matter? The Russian Experience', The Economics of Transition 11(3): 383-409. 
Table 1

List of research papers included in the meta-analysis

\begin{tabular}{|c|c|c|c|c|c|c|c|c|c|}
\hline & Researchers (year) & Country & Years of study & Type of Paper & $\begin{array}{l}\text { Dependant } \\
\text { Variable }\end{array}$ & $\begin{array}{l}\text { Definition of } \\
\text { Foreign ownership }\end{array}$ & $\begin{array}{l}\text { Type of } \\
\text { Data }\end{array}$ & $\begin{array}{l}\text { Aggregation } \\
\text { Level }\end{array}$ & Finding ${ }^{1}$ \\
\hline 1 & Aitken \& Harrison(1999) & Venezuela & 1976-1989 & Journal article & TFP, Output growth & Employment share & Panel & Firm & Negative \\
\hline 2 & Aslanoglu (2000) & Turkey & 1993 & Journal article & Labour prod. & Capital share & Cross Sec. & Industry & No impact \\
\hline 3 & Batra et al (2003) & Malaysia & $1985-1995$ & Working paper & Labour prod. & Employment share & Panel & Firm & Positive \\
\hline 4 & Björk (2005) & Chile & 2000 & Working paper & Output growth & Output share & Cross Sec. & Firm & Positive \\
\hline 5 & Blomström \& Persson(1983) & Mexico & 1970 & Journal article & Labour prod. & Employment share & Cross Sec. & Industry & Positive \\
\hline 6 & Bwalya (2005) & Zambia & 1993-1995 & Journal article & Labour prod. & Employment share & Panel & Firm & No impact \\
\hline 7 & Chuang \& Lin (1999) & Taiwan & $1995-2000$ & Journal article & TFP & Capital share & Cross Sec. & Firm & Positive \\
\hline 8 & Cuyversetal (2008) & Cambodia & 2000 & Working paper & Labour prod. & Capital share & Cross Sec. & Firm & Positive \\
\hline 9 & Damijan et al. (2003). & Slovakia & 1994-1998 & Working paper & Output growth & Capital share & Panel & Firm & No impact \\
\hline 10 & Djankov \& Hoekman (2000) & Czech Republic & $1992-97$ & Working paper & Output/Sales & Capital share & Panel & Firm & Negative \\
\hline 11 & Haddad \& Harrison (1993) & Morocco & 1985-1989 & Journal article & Output growth & Capital share & Panel & Firm & No impact \\
\hline 12 & Kathuria (2002) & India & 1975/76-1988/89 & Journal article & TFP & Output share & Panel & Firm & Positive \\
\hline 13 & Kee (2005). & Bangladesh & 2004 & Working paper & TFP & Capital share & Panel & Firm & Positive \\
\hline 14 & $\operatorname{Kein}(2008)$ & Brazil & 2005 & Working paper & Labour prod. & Output share & Cross Sec. & Firm & Positive \\
\hline 15 & Kokko et al. (2001) & Uruguay & 2005 & Journal article & Labour prod. & Output share & Cross Sec. & Industry & Positive \\
\hline 16 & Kolasa (2008) & Poland & $1996-2003$ & Working paper & Output growth & Output share & Panel & Firm & Positive \\
\hline 17 & Konings (2001) & Romania & 1987-1994 & Journal article & Output growth & Output share & Panel & Firm & No impact \\
\hline 18 & Konings (2001) & Bulgaria & 1993-1997 & Working paper & Output growth & Output share & Panel & Firm & Negative \\
\hline 19 & Liu et al. (2001) & China & 1996, 1997 & Journal article & Labour prod. & Capital share & Panel & Industry & Positive \\
\hline 20 & Lutz \& Talavera (2004) & Ukraine & 1998, 1999 & Journal article & Labour prod. & Output share & Panel & Firm & Positive \\
\hline 21 & Marin \& Bell (2006) & Argentina & 1992-1996 & Journal article & Output growth & Employment share & Panel & Firm & Mixed \\
\hline 22 & Rattsø \& Stokke(2003) & Thailand & $1975-1996$ & Journal article & TFP & Capital share & Panel & Industry & Positive \\
\hline 23 & Sgard (2001) & Hungary & 1992-1999 & Working paper & TFP & Capital share & Panel & Firm & Indifference \\
\hline 24 & Sjöholm (1999) & Indonesia & 1980, 1991 & Journal article & Labour prod. & Output share & Cross Sec. & Firm & Positive \\
\hline 25 & Smarzynska (2002) & Lithuania & $1996-2000$ & Working paper & Output growth & Capital share & Panel & Firm & No impact \\
\hline 26 & Thuy (2005) & Vietnam & $1995-2002$ & Working paper & Labour prod. & Employment share & Panel & Industry & Positive \\
\hline 27 & Vahter (2004) & Slovenia & $1994-2000$ & Working paper & Labour prod. & Capital share & Panel & Firm & Positive \\
\hline 28 & Vahter (2004) & Estonia & $1996-2001$ & Working paper & Labour prod. & Capital share & Panel & Firm & No impact \\
\hline 29 & Waldkirch \& Ofosu (2010) & Ghana & 1992-1998 & Working paper & TFP & Capital share & Panel & Firm & Negative \\
\hline 30 & Yudaeva et al. (2003) & Russia & $1992-1997$ & Journal article & $\begin{array}{l}\text { Labour prod./output } \\
\text { growth }\end{array}$ & Output share & Panel & Firm & Mixed \\
\hline
\end{tabular}

Source: Own compilation based on data collected from listed empirical studies. ${ }^{1}$ The findings of the paper are based on the conclusion of the respective studies and not on the statistics from individual regressions. 
Table 2

Meta analysis: The effect of study characteristics on the magnitude of the t-statistic

\begin{tabular}{|c|c|c|c|}
\hline \multirow[t]{2}{*}{ Study Characteristics } & \multicolumn{3}{|c|}{ Ordinary Least Square estimates } \\
\hline & $(1)$ & $(2)$ & (3) \\
\hline \multirow[t]{2}{*}{ No of observations } & $0.222^{* * *}$ & $0.241 * * *$ & $0.240^{* * *}$ \\
\hline & $(0.0625)$ & $(0.0556)$ & $(0.0581)$ \\
\hline \multirow[t]{2}{*}{ Panel data used } & $-1.071 * *$ & $-0.809 *$ & $-0.809 *$ \\
\hline & $(0.423)$ & $(0.475)$ & $(0.478)$ \\
\hline \multirow[t]{2}{*}{ On an Asian country } & & $0.944 * * *$ & $0.944 * * *$ \\
\hline & & $(0.293)$ & $(0.293)$ \\
\hline \multirow[t]{2}{*}{ Published } & & & 0.00908 \\
\hline & & & $(0.233)$ \\
\hline \multirow[t]{2}{*}{ Dependent variable - labour prod. } & -0.0891 & 0.203 & 0.206 \\
\hline & $(0.294)$ & $(0.269)$ & $(0.272)$ \\
\hline \multirow[t]{2}{*}{ Dependent variable - output } & -0.0413 & 0.102 & 0.103 \\
\hline & $(0.351)$ & $(0.358)$ & $(0.354)$ \\
\hline \multirow[t]{2}{*}{ FDI measured as capital share } & $1.180^{* * *}$ & $0.979 * * *$ & $0.979 * * *$ \\
\hline & $(0.281)$ & $(0.287)$ & $(0.289)$ \\
\hline \multirow[t]{2}{*}{ FDI measures as output share } & $0.733^{* *}$ & 0.366 & 0.366 \\
\hline & $(0.341)$ & $(0.339)$ & $(0.341)$ \\
\hline \multirow[t]{2}{*}{ Developing country } & 0.433 & -0.0903 & -0.0900 \\
\hline & $(0.344)$ & $(0.401)$ & $(0.402)$ \\
\hline \multirow[t]{2}{*}{ Firm level data } & $-0.682 * *$ & $-0.683 * *$ & $-0.682 * *$ \\
\hline & $(0.310)$ & $(0.283)$ & $(0.287)$ \\
\hline \multirow[t]{2}{*}{ Research and development } & 0.260 & 0.116 & 0.116 \\
\hline & $(0.381)$ & $(0.397)$ & $(0.398)$ \\
\hline \multirow[t]{2}{*}{ Labour quality } & 0.416 & $0.732^{*}$ & $0.730 *$ \\
\hline & $(0.350)$ & $(0.392)$ & $(0.399)$ \\
\hline \multirow[t]{2}{*}{ Domestic firms only } & -0.0785 & 0.229 & 0.228 \\
\hline & $(0.290)$ & $(0.319)$ & $(0.320)$ \\
\hline \multirow[t]{2}{*}{ Constant } & 0.517 & -0.0541 & -0.0590 \\
\hline & $(0.882)$ & $(0.941)$ & $(0.939)$ \\
\hline Observations & 130 & 130 & 130 \\
\hline R-squared & 0.348 & 0.400 & 0.400 \\
\hline
\end{tabular}

Notes: a) Estimates based on data collected from empirical studies listed in Table $1 \mathrm{~b}$ ) ***, ** and * denote statistical significance at $1 \%, 5 \%$ and $10 \%$ levels respectively c) Heteroskedasticity consistent standard errors provided in parentheses. 
Table 3

The distribution of firms by ownership status

\begin{tabular}{lcccc}
\hline Year & $\begin{array}{c}\text { Joint } \\
\text { Ventures }\end{array}$ & $\begin{array}{c}\text { Domestic } \\
\text { firms }\end{array}$ & $\begin{array}{c}\text { Fully owned } \\
\text { foreign firms }\end{array}$ & Total \\
\hline 2003 & 44 & 489 & 70 & 603 \\
2007 & 41 & 920 & 96 & 1057 \\
2003 (in panel) & 14 & 155 & 22 & 191 \\
2007 (in panel) & 17 & 146 & 28 & 191 \\
\hline
\end{tabular}

Table 4

The distribution of firms by ownership and region in 2007 (percent)

\begin{tabular}{lll}
\hline & Domestic & Foreign \\
Cape Town & $49(33.5)$ & $2(4.40)$ \\
Durban & $11(7.50)$ & $6(13.3)$ \\
Johannesburg & $78(53.4)$ & $33(73.3)$ \\
Port Elizabeth & $8(5.50)$ & $4(8.80)$ \\
\hline
\end{tabular}

Table 5

Industrial distribution of domestic and foreign firms in 2007

\begin{tabular}{lcccc}
\hline Industry type & \multicolumn{2}{c}{ Domestic firms } & \multicolumn{2}{c}{ Foreign firms } \\
& $N$ & $\%$ & $N$ & $\%$ \\
\hline Other manufacturing & 30 & 20.55 & 9 & 20 \\
Food & 17 & 11.64 & 6 & 13.3 \\
Textiles & 3 & 2.054 & 1 & 2.22 \\
Garments & 12 & 8.219 & 2 & 4.44 \\
Chemicals & 20 & 13.69 & 8 & 17.8 \\
Plastics and rubber & 10 & 6.849 & 2 & 4.44 \\
Non metallic mineral products & 1 & 0.685 & 1 & 2.22 \\
Basic metals & 2 & 1.369 & 0 & 0 \\
Fabricated metal products & 21 & 14.38 & 13 & 28.9 \\
Machinery and equipment & 15 & 10.27 & 1 & 2.22 \\
Electronics & 9 & 6.164 & 2 & 4.44 \\
Other Services & 1 & 0.685 & 0 & 0 \\
Retail & 3 & 2.054 & 0 & 0 \\
Hotels and restaurants & 1 & 0.685 & 0 & 0 \\
Transport & 1 & 0.685 & 0 & 0 \\
\hline
\end{tabular}


Table 6

Description of dependent and independent Variables

\begin{tabular}{ll}
\hline \multicolumn{1}{c}{ Variable } & \multicolumn{1}{c}{ Description } \\
\hline Labour productivity & Annual firm sales per worker (measured in local currency units) \\
FDI_Firm & Share of firm equity held by foreigners \\
FDI_Industry & Share of industry equity held by foreigners (weighted by fixed capital) \\
FDI_Joint venture & Share of industry equity held by joint ventures \\
FDI_fully owned & Share of industry equity that is fully owned by foreigners \\
Capital per worker & Fixed capital (net book value of machinery, vehicles and equipment) per worker \\
Quality certification & Internationally-recognized quality certification (e.g. ISO 9000, 9002) \\
Labour_quality & Proportion of skilled production workers \\
Firm size (5-19) & Small size firm (5-19 employees) \\
Firm size (20-99) & Medium size firm (20-99 employees) \\
Firm size (100+) & Large size firm (100 employees and more) \\
Firm age & The age of the firm \\
BEE_material & Percentage of a firm's domestically sourced material inputs that are purchased \\
BEE_time & from a black empowered firm (only available for 2007) \\
& Percentage of senior management time spent on issues pertaining to BEE in a \\
\end{tabular}

Table 7

Descriptive statistics (only for firms in the panel)

\begin{tabular}{lcc}
\hline Variable & \multicolumn{2}{c}{ Mean (Std. Dev.) } \\
\cline { 2 - 3 } & 2003 & 2007 \\
\hline Log of labour productivity & $19.913(1.47)$ & $13.0733(0.9457)$ \\
FDI_Firm & $0.153(0.341)$ & $0.1837(0.3668)$ \\
FDI_Industry & $0.290(0.282)$ & $0.2835(0.2856)$ \\
FDI_Joint venture & $0.079(0.17)$ & $0.0730(0.1688)$ \\
FDI_fully owned & $0.211(0.269)$ & $0.2105(0.2729)$ \\
Log of capital per worker & $17.56(1.24)$ & $10.840(2.0058)$ \\
Quality certification & $0.434(0.497)$ & $0.602(0.490)$ \\
Labour_quality & $0.381(0.384)$ & $0.4497(0.2781)$ \\
Firm size (5-19) & $0.068(0.2525)$ & $0.0628(0.2433)$ \\
Firm size (20-99) & $0.424(0.4955)$ & $0.3613(0.4816)$ \\
Firm size (100+) & $0.508(0.5013)$ & $0.5759(0.4955)$ \\
Firm age & $25.43(22.14)$ & $29.0105(22.0442)$ \\
BEE_material & 0 & $16.17(23.67)$ \\
BEE_time & 0 & $5.64(12.22)$ \\
\hline
\end{tabular}

Notes: In 2003, the number of observations $(N)=179$ for labour productivity, 151 for capital per worker, 182 for labour quality and 191 for the rest of the variables. In 2007, $N$ is 179 for capital per worker, 185 for labour quality, 175 for BEE_material, 184 for BEE_material and 191 for the rest of the variables. 
Table 8

Descriptive statistics (only for firms in the panel)

\begin{tabular}{lcccc}
\hline Variable & \multicolumn{3}{c}{ Mean (Std. Dev.) } \\
& Domestic firms & \multicolumn{3}{c}{ Foreign firms } \\
\cline { 2 - 5 } & 2003 & 2007 & 2003 & 2007 \\
\hline Log of labour productivity & 19.8623 & 12.9384 & 20.1187 & 13.5110 \\
FDI_Firm & $(1.577)$ & $(0.8967)$ & $(0.9532)$ & $(0.9778)$ \\
& 0.0 & 0.0 & 0.7914 & 0.7796 \\
FDI_Industry & $(0.0)$ & $(0.0)$ & $(0.3066)$ & $(0.3254)$ \\
FDI_Joint venture & 0.2894 & 0.2836 & 0.2930 & 0.2833 \\
& $(0.2849)$ & $(0.2893)$ & $(0.2738)$ & $(0.2766)$ \\
FDI_fully owned & 0.07774 & 0.0753 & 0.0849 & 0.0653 \\
Log of capital per worker & $(0.1699)$ & $(0.1728)$ & $(0.1730)$ & $(0.1564)$ \\
& 0.2117 & 0.2082 & 0.2081 & 0.2180 \\
Quality certification & $(0.2707)$ & $(0.2753)$ & $(0.2652)$ & $(0.2679)$ \\
Labour_quality & 17.5748 & 10.7371 & 17.5015 & 11.1568 \\
Firm size (5-19) & $(1.2161)$ & $(1.9865)$ & $(1.3481)$ & $(2.0546)$ \\
Firm size (20-99) & 0.363 & 0.520 & 0.729 & 0.866 \\
Firm size (100+) & $(0.482)$ & $(0.501)$ & $(0.450)$ & $(0.343)$ \\
Firm age & 0.3799 & 0.4351 & 0.3835 & 0.4951 \\
BEE_material & $(0.4114)$ & $(0.2945)$ & $(0.2409)$ & $(0.2160)$ \\
BEE_time & 0.0844 & 0.0822 & 0.0000 & 0.0000 \\
& $(0.2789)$ & $(0.2756)$ & $(0.0000)$ & $(0.0000)$ \\
& 0.4740 & 0.4315 & 0.2162 & 0.1333 \\
& $(0.5010)$ & $(0.4970)$ & $(0.4173)$ & $(0.3438)$ \\
& 0.4416 & 0.4863 & 0.7838 & 0.8667 \\
& $(0.4982)$ & $(0.5015)$ & $(0.4173)$ & $(0.3438)$ \\
& 23.7662 & 28.0480 & 32.3514 & 32.1333 \\
& $(21.1248)$ & $(22.8863)$ & $(25.1166)$ & $(18.9540)$ \\
& 0 & 16.94 & 0 & 13.8 \\
& & $(24.09)$ & & $(22.45)$ \\
& & 6.29 & 0 & 3.36 \\
& $(13.69)$ & & $(3.45)$ \\
\hline
\end{tabular}


Table 9

The effect of foreign direct investment (equity based measure) on labour productivity

\begin{tabular}{|c|c|c|c|c|c|c|c|}
\hline \multirow[b]{2}{*}{ VARIABLES } & \multicolumn{2}{|c|}{ OLS 2003} & \multicolumn{2}{|c|}{ OLS 2007} & \multicolumn{2}{|c|}{$\begin{array}{l}\text { Pooled } \\
\text { OLS }\end{array}$} & \multirow{2}{*}{$\begin{array}{l}\text { Fixed Effects } \\
\text { Panel } \\
\text { sample } \\
(7)\end{array}$} \\
\hline & $\begin{array}{c}\text { Full } \\
\text { sample } \\
(1)\end{array}$ & $\begin{array}{c}\text { Panel } \\
\text { sample } \\
(2)\end{array}$ & $\begin{array}{c}\text { Full } \\
\text { sample } \\
\text { (3) }\end{array}$ & $\begin{array}{c}\text { Panel } \\
\text { sample } \\
(4)\end{array}$ & $\begin{array}{c}\text { Full } \\
\text { sample } \\
(5)\end{array}$ & $\begin{array}{c}\text { Panel } \\
\text { sample } \\
(6)\end{array}$ & \\
\hline Log-capital per worker & $\begin{array}{c}0.310^{* * *} \\
(0.0508)\end{array}$ & $\begin{array}{c}0.418^{* * *} \\
(0.123)\end{array}$ & $\begin{array}{c}0.194 * * * \\
(0.0219)\end{array}$ & $\begin{array}{c}0.136 * * * \\
(0.0380)\end{array}$ & $\begin{array}{c}0.233^{* * *} \\
(0.0236)\end{array}$ & $\begin{array}{c}0.213^{* * *} \\
(0.0505)\end{array}$ & $\begin{array}{c}0.187 * * \\
(0.0757)\end{array}$ \\
\hline FDI_Firm & $\begin{array}{l}0.497 * \\
(0.301)\end{array}$ & $\begin{array}{c}0.360 \\
(0.355)\end{array}$ & $\begin{array}{c}0.295 \\
(0.192)\end{array}$ & $\begin{array}{c}0.342 \\
(0.297)\end{array}$ & $\begin{array}{c}0.394^{* *} \\
(0.165)\end{array}$ & $\begin{array}{c}0.274 \\
(0.234)\end{array}$ & $\begin{array}{l}-0.837 \\
(0.456)\end{array}$ \\
\hline FDI_Industry & $\begin{array}{l}-0.311 \\
(0.305)\end{array}$ & $\begin{array}{l}0.0327 \\
(0.318)\end{array}$ & $\begin{array}{l}0.0269 \\
(0.129)\end{array}$ & $\begin{array}{l}-0.289 \\
(0.252)\end{array}$ & $\begin{array}{c}-0.0749 \\
(0.122)\end{array}$ & $\begin{array}{l}-0.280 \\
(0.198)\end{array}$ & $\begin{array}{c}0.993 \\
(1.050)\end{array}$ \\
\hline FDI_Firm*FDI_Industry & $\begin{array}{l}-0.314 \\
(0.715)\end{array}$ & $\begin{array}{l}-0.767 \\
(0.737)\end{array}$ & $\begin{array}{l}-0.698 \\
(0.434)\end{array}$ & $\begin{array}{c}0.194 \\
(0.650)\end{array}$ & $\begin{array}{l}-0.531 \\
(0.378)\end{array}$ & $\begin{array}{l}-0.247 \\
(0.471)\end{array}$ & $\begin{array}{c}1.436 \\
(1.019)\end{array}$ \\
\hline Year (2007) & 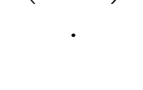 & 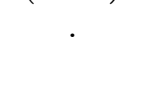 & 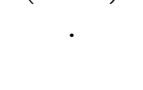 & 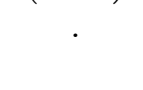 & $\begin{array}{c}-5.468^{* * *} \\
(0.161)\end{array}$ & $\begin{array}{c}-5.522^{* * * *} \\
(0.320)\end{array}$ & $\begin{array}{c}-5.530 * * * \\
(0.511)\end{array}$ \\
\hline Observations & 473 & 147 & 650 & 179 & 1,123 & 326 & 326 \\
\hline R-squared & 0.266 & 0.340 & 0.288 & 0.229 & 0.935 & 0.929 & 0.967 \\
\hline
\end{tabular}

Notes: Robust standard errors in parentheses; ${ }^{* * *} \mathrm{p}<0.01,{ }^{*} * \mathrm{p}<0.05,{ }^{*} \mathrm{p}<0.1$; Other regressors include the number of skilled production workers, whether a firm has an international quality certificate and indicator variables for firm size.

Table 10

The effect of foreign direct investment (employment based measure) on labour productivity

\begin{tabular}{|c|c|c|c|c|c|c|c|}
\hline \multirow[b]{2}{*}{ VARIABLES } & \multicolumn{2}{|c|}{ OLS 2003} & \multicolumn{2}{|c|}{ OLS 2007} & \multicolumn{2}{|c|}{$\begin{array}{l}\text { Pooled } \\
\text { OLS }\end{array}$} & \multirow{2}{*}{$\begin{array}{l}\text { Fixed Effects } \\
\text { Panel } \\
\text { sample } \\
(7)\end{array}$} \\
\hline & $\begin{array}{c}\text { Full } \\
\text { sample } \\
(1)\end{array}$ & $\begin{array}{c}\text { Panel } \\
\text { sample } \\
(2)\end{array}$ & $\begin{array}{c}\text { Full } \\
\text { sample } \\
\text { (3) }\end{array}$ & $\begin{array}{c}\text { Panel } \\
\text { sample } \\
(4)\end{array}$ & $\begin{array}{c}\text { Full } \\
\text { sample } \\
(5)\end{array}$ & $\begin{array}{c}\text { Panel } \\
\text { sample } \\
(6)\end{array}$ & \\
\hline Log-capital per worker & $\begin{array}{c}0.325^{* * *} \\
(0.0505)\end{array}$ & $\begin{array}{c}0.416^{* * *} \\
(0.124)\end{array}$ & $\begin{array}{c}0.195^{* * *} \\
(0.0219)\end{array}$ & $\begin{array}{c}0.147 * * * \\
(0.0374)\end{array}$ & $\begin{array}{c}0.237 * * * \\
(0.0234)\end{array}$ & $\begin{array}{c}0.217 * * * \\
(0.0504)\end{array}$ & $\begin{array}{c}0.180 * * \\
(0.0856)\end{array}$ \\
\hline FDI_Firm & $\begin{array}{c}0.000538^{* *} \\
(0.000228)\end{array}$ & $\begin{array}{l}-0.000221 \\
(0.000549)\end{array}$ & $\begin{array}{c}0.000904 \\
(0.000712)\end{array}$ & $\begin{array}{l}0.00127 * * \\
(0.000639)\end{array}$ & $\begin{array}{c}0.000424^{* *} \\
(0.000170)\end{array}$ & $\begin{array}{c}0.000573 \\
(0.000630)\end{array}$ & $\begin{array}{c}-0.000846 \\
(0.00188)\end{array}$ \\
\hline FDI_Industry & $\begin{array}{c}0.228 \\
(0.387)\end{array}$ & $\begin{array}{c}0.307 \\
(0.584)\end{array}$ & $\begin{array}{l}-0.192 \\
(0.340)\end{array}$ & $\begin{array}{l}-0.488 \\
(0.546)\end{array}$ & $\begin{array}{l}-0.224 \\
(0.274)\end{array}$ & $\begin{array}{l}-0.492 \\
(0.381)\end{array}$ & $\begin{array}{c}2.176 \\
(2.724)\end{array}$ \\
\hline FDI_Firm*FDI_Industry & $\begin{array}{l}-0.00144 * \\
(0.000763)\end{array}$ & $\begin{array}{c}-0.000449 \\
(0.00126)\end{array}$ & $\begin{array}{l}-0.00218 \\
(0.00166)\end{array}$ & $\begin{array}{l}-0.00283^{*} \\
(0.00150)\end{array}$ & $\begin{array}{l}-0.00108^{* *} \\
(0.000496)\end{array}$ & $\begin{array}{l}-0.00150 \\
(0.00143)\end{array}$ & $\begin{array}{c}0.00300 \\
(0.00702)\end{array}$ \\
\hline Year (2007) & . & . & . & . & $\begin{array}{c}-5.413^{* * *} \\
(0.160)\end{array}$ & $\begin{array}{c}-5.501 * * * \\
(0.319)\end{array}$ & $\begin{array}{c}-5.598^{* * * *} \\
(0.570)\end{array}$ \\
\hline Observations & 473 & 147 & 650 & 179 & 1,123 & 326 & 326 \\
\hline R-squared & 0.257 & 0.340 & 0.287 & 0.225 & 0.935 & 0.929 & 0.966 \\
\hline
\end{tabular}

Notes: Robust standard errors in parentheses; ${ }^{* * *} \mathrm{p}<0.01,{ }^{* *} \mathrm{p}<0.05,{ }^{*} \mathrm{p}<0.1$; Other regressors include the number of skilled production workers, whether a firm has an international quality certificate and indicator variables for firm size. 
Table 11

The effect of foreign direct investment and black economic empowerment on labour productivity

\begin{tabular}{|c|c|c|c|c|c|c|}
\hline \multirow[b]{2}{*}{ VARIABLES } & \multicolumn{2}{|c|}{ OLS 2007} & \multicolumn{2}{|c|}{ OLS 2007} & \multicolumn{2}{|c|}{ Fixed Effects } \\
\hline & $\begin{array}{c}\text { Full } \\
\text { sample } \\
(1)\end{array}$ & $\begin{array}{c}\text { Panel } \\
\text { sample } \\
(2)\end{array}$ & $\begin{array}{c}\text { Full } \\
\text { sample } \\
(3)\end{array}$ & $\begin{array}{c}\text { Panel } \\
\text { sample } \\
(4)\end{array}$ & $\begin{array}{c}\text { Panel } \\
\text { sample } \\
(5)\end{array}$ & $\begin{array}{c}\text { Panel } \\
\text { sample } \\
\text { (6) }\end{array}$ \\
\hline Log of capital per worker & $\begin{array}{c}0.193^{* * *} \\
(0.022)\end{array}$ & $\begin{array}{c}0.140^{* * *} \\
(0.0374)\end{array}$ & $\begin{array}{c}0.188^{* * *} \\
(0.021)\end{array}$ & $\begin{array}{c}0.133^{* * * *} \\
(0.038)\end{array}$ & $\begin{array}{c}0.194 * * \\
(0.077)\end{array}$ & $\begin{array}{c}0.192^{* *} \\
(0.075)\end{array}$ \\
\hline FDI_Firm & $\begin{array}{c}0.289 \\
(0.189)\end{array}$ & $\begin{array}{c}0.361^{* *} \\
(0.286)\end{array}$ & $\begin{array}{c}0.409 * * \\
(0.200)\end{array}$ & $\begin{array}{l}0.587^{*} \\
(0.307)\end{array}$ & $\begin{array}{c}-0.822^{*} \\
(0.462)\end{array}$ & $\begin{array}{c}-0.901 * \\
(0.480)\end{array}$ \\
\hline FDI_Industry & $\begin{array}{c}0.040 \\
(0.129)\end{array}$ & $\begin{array}{l}-0.224 \\
(0.257)\end{array}$ & $\begin{array}{c}0.112 \\
(0.164)\end{array}$ & $\begin{array}{l}-0.255 \\
(0.316)\end{array}$ & $\begin{array}{l}1.076 \\
(1.01)\end{array}$ & $\begin{array}{c}1.342 \\
(1.091)\end{array}$ \\
\hline FDI_Firm*FDI_Industry & $\begin{array}{l}-0.661 \\
(0.418)\end{array}$ & $\begin{array}{c}0.066 \\
(0.640)\end{array}$ & $\begin{array}{l}-0.463 \\
(0.388)\end{array}$ & $\begin{array}{c}0.007 \\
(0.643)\end{array}$ & $\begin{array}{c}1.442 \\
(0.969)\end{array}$ & $\begin{array}{c}1.516 \\
(0.975)\end{array}$ \\
\hline BEE_material & $\begin{array}{c}-0.0024^{* *} \\
(0.0012)\end{array}$ & $\begin{array}{c}-0.005^{*} \\
(0.003)\end{array}$ & $\begin{array}{c}-0.0006 \\
(0.00200)\end{array}$ & $\begin{array}{c}-0.0022 \\
(0.004)\end{array}$ & $\begin{array}{l}-0.005 \\
(0.004)\end{array}$ & $\begin{array}{l}-0.002 \\
(0.005)\end{array}$ \\
\hline FDI_Firm*BEE_material & ( & 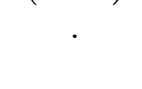 & $\begin{array}{c}-0.008^{* *} \\
(0.0036)\end{array}$ & $\begin{array}{c}-0.015^{*} \\
(0.006)\end{array}$ & 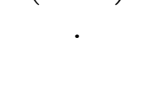 & $\begin{array}{c}0.003 \\
(0.006)\end{array}$ \\
\hline FDI_Ind.*BEE_material & . & . & $\begin{array}{l}-0.003 \\
(0.004)\end{array}$ & $\begin{array}{l}0.0006 \\
(0.009)\end{array}$ & . & $\begin{array}{l}-0.010 \\
(0.012)\end{array}$ \\
\hline Year (2007) & . & . & . & . & $\begin{array}{c}-5.389 * * * \\
(0.561)\end{array}$ & $\begin{array}{c}-5.393 * * * \\
(0.552)\end{array}$ \\
\hline Observations & 650 & 178 & 649 & 178 & 325 & 325 \\
\hline R-squared & 0.310 & 0.246 & 0.297 & 0.266 & 0.967 & 0.967 \\
\hline
\end{tabular}

Notes: Robust standard errors in parentheses; *** $\mathrm{p}<0.01, * * \mathrm{p}<0.05, * \mathrm{p}<0.1$; Other regressors include the number of skilled production workers, whether a firm has an international quality certificate and indicator variables for firm size. 
Table A1

Descriptive statistics for variables included in the meta analysis

\begin{tabular}{lcc} 
Variables & Mean & $\begin{array}{c}\text { Standard } \\
\text { Dev. }\end{array}$ \\
\hline Absolute value of t-statistic & 2.046238 & 1.3443 \\
Magnitude of Coefficient & .4286131 & 1.143338 \\
No.of observations & 14405.6 & 24929.8 \\
Labour productivity & .3846154 & .4883863 \\
Total factor productivity & .1384615 & .3467199 \\
Output & .4769231 & .5013994 \\
Employment share & .2384615 & .4277913 \\
Capital share & .4538462 & .4997913 \\
Output share & .3076923 & .4633239 \\
Cross section data & .2153846 & .4126792 \\
Panel data & .7846154 & .4126792 \\
Industry level data & .1615385 & .3694506 \\
Firm level data & .8384615 & .3694506 \\
Publication & .6307692 & .4844634 \\
Transition country & .6538462 & .4775834 \\
Developing country & .3461538 & .4775834 \\
Labour quality & .3461538 & .4775834 \\
R\&D Dummy & .2461538 & .4324357 \\
Spillover for all firms & .4538462 & .4997913 \\
Spillover for domestic firms & .5461538 & .4997913 \\
$N$ & 130 &. \\
\hline
\end{tabular}

Notes: Own calculations based on data collected from studies listed in Table 1 
Table A2

Testing for sample attrition - Probability of dropping out of the sample

\begin{tabular}{ll}
\hline VARIABLES & $\begin{array}{c}\text { Marginal } \\
\text { effects }\end{array}$ \\
\hline Labour productivity & -0.032 \\
& $(0.022)$ \\
FDI share & 0.019 \\
& $(0.065)$ \\
Capital per labour & -0.007 \\
R\&D Dummy & $(0.181)$ \\
& 0.051 \\
Labour quality & $(0.047)$ \\
& -0.056 \\
Firm size (20-99 employees) & $(0.071)$ \\
& -0.065 \\
Firm size (100+ employees) & $(0.080)$ \\
& -0.106 \\
& $(0.081)$
\end{tabular}

N

473

Notes: Heteroskedasticity consistent standard errors are in parentheses. 
Table A3

The effect of foreign direct investment (equity based measure) including regional foreign ownership

\begin{tabular}{|c|c|c|c|c|c|c|c|}
\hline \multirow[b]{2}{*}{ VARIABLES } & \multicolumn{2}{|c|}{ OLS 2003} & \multicolumn{2}{|c|}{ OLS 2007} & \multicolumn{2}{|c|}{ POLS } & \multirow{2}{*}{$\frac{\text { Fixed Effects }}{\text { Panel }}$} \\
\hline & Full & Panel & Full & Panel & Full & Panel & \\
\hline \multirow[t]{2}{*}{ Log-capital per worker } & $0.310^{* * *}$ & $0.416^{* * *}$ & $0.194^{* * *}$ & $0.137 * * *$ & $0.233^{* * *}$ & $0.213^{* * *}$ & $0.188^{* *}$ \\
\hline & $(0.0512)$ & $(0.125)$ & $(0.0219)$ & $(0.0375)$ & $(0.0237)$ & $(0.0505)$ & $(0.0851)$ \\
\hline \multirow[t]{2}{*}{ FDI_Firm } & 0.502 & 0.366 & 0.289 & 0.376 & $0.397 * *$ & 0.284 & $-0.852^{*}$ \\
\hline & $(0.307)$ & $(0.363)$ & $(0.191)$ & $(0.303)$ & $(0.165)$ & $(0.237)$ & $(0.510)$ \\
\hline \multirow[t]{2}{*}{ FDI_Region_Industry } & -22.21 & -21.97 & 0.0513 & -0.176 & -0.0428 & -0.0673 & 0.100 \\
\hline & $(49.05)$ & $(51.12)$ & $(0.154)$ & $(0.242)$ & $(0.139)$ & (0.194) & $(0.301)$ \\
\hline \multirow[t]{2}{*}{ FDI_Industry } & 21.96 & 22.07 & 0.0277 & -0.281 & -0.0677 & -0.249 & 1.011 \\
\hline & $(49.32)$ & $(51.37)$ & $(0.129)$ & $(0.253)$ & $(0.124)$ & $(0.220)$ & $(1.167)$ \\
\hline \multirow[t]{2}{*}{ FDI_Firm*FDI_Industry } & -0.325 & -0.778 & -0.695 & 0.182 & -0.531 & -0.252 & 1.427 \\
\hline & $(0.727)$ & $(0.746)$ & $(0.434)$ & $(0.654)$ & $(0.378)$ & $(0.472)$ & $(1.168)$ \\
\hline \multirow[t]{2}{*}{ Year (2007) } & . & . & . & . & $-5.468 * * *$ & $-5.521 * * *$ & $-5.522 * * *$ \\
\hline & & & & & $(0.161)$ & $(0.320)$ & $(0.575)$ \\
\hline \multirow[t]{2}{*}{ Constant } & $14.17^{* * *}$ & $12.51 * * *$ & $10.16^{* * *}$ & $11.34^{* * *}$ & $15.16^{* * *}$ & $16.07 * * *$ & $16.46^{* * *}$ \\
\hline & $(0.875)$ & $(1.977)$ & $(0.269)$ & $(0.507)$ & $(0.411)$ & $(0.772)$ & $(1.437)$ \\
\hline Observations & 473 & 147 & 650 & 179 & 1,123 & 326 & 326 \\
\hline R-squared & 0.266 & 0.341 & 0.288 & 0.231 & 0.935 & 0.929 & 0.967 \\
\hline
\end{tabular}

Notes: Robust standard errors in parentheses; *** $\mathrm{p}<0.01, * * \mathrm{p}<0.05,{ }^{*} \mathrm{p}<0.1$; Other regressors include the number of skilled production workers, whether a firm has an international quality certificate and indicator variables for firm size. 
Table A4

Effect of foreign ownership in 2003 on labour productivity in 2007

\begin{tabular}{ll}
\hline VARIABLES & LLProd \\
\hline Log capital per worker & $0.130^{* * *}$ \\
& $(0.039)$ \\
FDI_firm in 2003 & $0.619^{* * *}$ \\
& $(0.288)$ \\
FDI_Industry in 2003 & -0.261 \\
& $(0.263)$ \\
FDI_firm*FDI_Industry in 2003 & -0.150 \\
& $(0.536)$ \\
Observations & 182 \\
R-squared & 0.248 \\
\hline
\end{tabular}

Robust standard errors in parentheses

$$
\text { *** } \mathrm{p}<0.01, * * \mathrm{p}<0.05, * \mathrm{p}<0.1
$$


Table A5

The effect of foreign direct investment (equity based measure) on labour productivity

\begin{tabular}{lccccccc}
\hline & \multicolumn{2}{c}{ OLS 2003} & \multicolumn{2}{c}{ OLS 2007} & \multicolumn{2}{c}{ POLS } & $\begin{array}{c}\text { Fixed } \\
\text { Effects }\end{array}$ \\
\cline { 2 - 8 } VARIABLES & Full & Panel & Full & Panel & Full & Panel & Panel \\
\hline Log-capital per worker & $0.310^{* * *}$ & $0.418^{* * *}$ & $0.185^{* * *}$ & $0.129 * * *$ & $0.231^{* * *}$ & $0.214^{* * *}$ & $0.187^{* *}$ \\
& $(0.0508)$ & $(0.123)$ & $(0.0222)$ & $(0.0375)$ & $(0.0240)$ & $(0.0505)$ & $(0.0829)$ \\
FDI_Firm & 0.496 & 0.358 & 0.167 & 0.374 & 0.341 & 0.382 & -0.533 \\
& $(0.301)$ & $(0.355)$ & $(0.292)$ & $(0.565)$ & $(0.225)$ & $(0.309)$ & $(0.542)$ \\
FDI_Industry & -0.311 & 0.0316 & $0.630^{* *}$ & 0.296 & 0.216 & -0.0319 & -0.196 \\
& $(0.304)$ & $(0.316)$ & $(0.277)$ & $(0.412)$ & $(0.208)$ & $(0.244)$ & $(0.384)$ \\
FDI_Firm*FDI_Industry & -0.312 & -0.762 & -0.187 & 0.0400 & -0.332 & -0.567 & 0.233 \\
& $(0.714)$ & $(0.735)$ & $(0.799)$ & $(1.394)$ & $(0.577)$ & $(0.697)$ & $(1.177)$ \\
Year (2007) &. &. &. &. & $-5.466^{* * *}$ & $-5.515^{* * *}$ & $-5.533^{* * *}$ \\
& & & & & $(0.162)$ & $(0.320)$ & $(0.563)$ \\
Constant & $14.18^{* * *}$ & $12.49 * * *$ & $10.06 * * *$ & $11.19 * * *$ & $15.07 * * *$ & $16.01 * * *$ & $16.85^{* * *}$ \\
& $(0.876)$ & $(1.955)$ & $(0.269)$ & $(0.522)$ & $(0.410)$ & $(0.771)$ & $(1.341)$ \\
Observations & 473 & 147 & 650 & 179 & 1,123 & 326 & 326 \\
R-squared & 0.266 & 0.340 & 0.293 & 0.226 & 0.935 & 0.929 & 0.967 \\
\hline
\end{tabular}

Notes: Robust standard errors in parentheses; ${ }^{* * *} \mathrm{p}<0.01, * * \mathrm{p}<0.05,{ }^{*} \mathrm{p}<0.1$; Other regressors include the number of skilled production workers, whether a firm has an international quality certificate and indicator variables for firm size. The measure of FDI at the industry level is based on using information on all firms and not just those included in the regressions. 